\title{
Novel Mutations Detected from Drug Resistant Mycobacterium Tuberculosis Isolated from North East of Thailand
}

\section{Ei Phoo Thwe}

Khon Kaen University Faculty of Technology

\section{Wises Namwat}

Khon Kaen University Faculty of Medicine

\section{Porntip Pinlaor}

Department of Clinical Microbiology, Faculty of Associated Medical Sciences, Khon Kaen University

Kulrattana Rueangsak

Product Specialist at Thai Diagnostics Co., Ltd, Bangkok

Arunnee Sangka ( $\nabla$ arusan@kku.ac.th )

Khon Kaen University Faculty of Associated Medical Sciences https://orcid.org/0000-0002-0859-9017

\section{Research Article}

Keywords: drug-resistant, Mycobacterium tuberculosis, mutation, rpoB, katG

Posted Date: July 7th, 2021

DOl: https://doi.org/10.21203/rs.3.rs-648869/v1

License: (c) (i) This work is licensed under a Creative Commons Attribution 4.0 International License. Read Full License 
Novel mutations detected from drug resistant Mycobacterium tuberculosis isolated from North East of Thailand

Ei Phoo Thwe $e^{\mathrm{a}, \mathrm{c}}$, Wises Namwat ${ }^{\mathrm{b}}$, Porntip Pinlaor ${ }^{\mathrm{c}, \mathrm{e}}$, Kulrattana Rueangsak $^{\mathrm{d}}$, Arunnee Sangka ${ }^{\mathrm{c}, \mathrm{e}}$

${ }^{a}$ Medical Technology Program, Faculty of Associated Medical Sciences, Khon Kaen University, Khon Kaen, Thailand

${ }^{b}$ Department of Microbiology, Faculty of Medicine, Khon Kaen University, Khon Kaen, Thailand

${ }^{\mathrm{c}}$ Centre for Research and Development of Medical Diagnostic Laboratories (CMDL), Faculty of Associated Medical Sciences, Khon Kaen University, Khon Kaen, Thailand

dProduct Specialist at Thai Diagnostics Co., Ltd, Bangkok, Thailand 10250

eDepartment of Clinical Microbiology, Faculty of Associated Medical Sciences, Khon Kaen University, Khon Kaen, Thailand

* Corresponding author at: Department of Microbiology, Faculty of Associated Medical Sciences, Khon Kaen University, Khon Kaen 40002, Thailand E-mail address: arusan@kku.ac.th

(A. Sangka). 


\begin{abstract}
The emergence of drug-resistant tuberculosis is a major global public health threat. Thailand is one of the top 14 countries with high tuberculosis, tuberculosis co-infected with Human Immunodeficiency Virus (HIV) and multi-drug resistant tuberculosis rates. Immediate detection of drug-resistant tuberculosis is necessary to reduce mortality and morbidity by effectively providing treatment to ameliorate the formation of resistant strains. Limited data exist of mutation profiles in Northeastern Thailand. Here, 65 drug-resistant Mycobacterium tuberculosis isolates were used to detect mutations by polymerase chain reaction (PCR) and DNA sequencing. In the $k a t G$ gene, mutations occurred in 47(79.7\%) among 59 isoniazid resistant samples. For $r p o B$ gene, 31 (96.9\%) were observed as mutations in 32 rifampicin resistant isolates. Of $47 \mathrm{katG}$ mutation samples, 45 (95.7\%) had mutations in katG315 codon and $2(4.3 \%)$ showed novel mutations at katG365 with amino acid substitution of CCG-CGG (ProArg). Moreover, 18 (58.1\%) mutations at rpoB531, 11 (35.5\%) mutations at rpoB516, $10(32.3 \%)$ mutations at rpoB526 and 1 (3.2\%) mutation at rpoB533 were found between 31 rifampicin resistant samples. Common and novel mutations of the $r p o B$ and $k a t G$ genes in Northeastern Thailand were generated. DNA sequencing showed high accuracy, while conventional polymerase chain reaction could be applied as an initial marker for screening rifampicin and isoniazid drug-resistant Mycobacterium tuberculosis in Northeastern Thailand. Mutations reported here should be considered when developing new molecular diagnostic methods for implementation in Northeastern Thailand.
\end{abstract}

Keywords: drug-resistant, Mycobacterium tuberculosis, mutation, rpoB, katG 


\section{Introduction}

Tuberculosis (TB) caused by Mycobacterium tuberculosis (MTB) bacteria is a serious global infectious disease even though diagnosis and treatment are available. About one fourth of population (10 million people) in the world is suffering from this disease, with death rates of 1.4 million people in 2019 (World Health Organization 2020). The emergence of multi-drug resistant TB (MDR TB), described as resistant to at least rifampicin and isoniazid, as the two most commonly applied powerful first-line antiTB drugs, is also a major public health threat worldwide (Lange et al. 2019) (Jang and Chung 2020). Globally in 2019, an estimated 465,000 incident cases were reported as MDR and rifampicin resistant (RR) TB, while $3.3 \%$ and $13 \%$ of new cases and $18 \%$ and $17.4 \%$ of previously treated cases were diagnosed with MDR/RR TB and isoniazid (INH) resistant TB, respectively (World Health Organization 2020). Thailand is one of the top 14 countries with high TB, TB/HIV and MDR-TB and had 150 TB cases per 100,000 population in 2019 (World Health Organization 2020) (Anukool et al. 2020). Immediate detection and accurate identification of MDR-TB is necessary to reduce mortality and morbidity by effectively providing treatment, to ameliorate the formation and spread of resistant strains (Jaksuwan et al. 2017)(Nimri et al. 2011)(Prammananan et al. 2008). The phenotypic DST method is the gold standard for detection of drug resistance but this takes 2-3 months to yield results and also increases the risk of bacterial contamination and cross infection by non-tuberculous mycobacterial infection. To shorten the turnaround time, rapid molecular diagnostic polymerase chain reaction (PCR) and DNA sequencing methods were selected in this study (Genestet et al. 2020; Li et al. 2020; Jang and Chung 2020). The distribution of drug-resistant genes varies according to geographical locations and identifying the mutation patterns of MDR-TB is important to optimize the treatment protocol (Jaksuwan et al. 2017) (Seifert et al. 2015). However, limited data exist of mutation profiles in Northeastern Thailand.

A better understanding of drug-resistant mechanisms and the most commonly found mutation codons of rifampicin (RIF) and isoniazid (INH) is required. RIF is one of the most effective anti-TB drugs. Its mode of action involves binding to the $\beta$-subunit of RNA polymerase, thereby inhibiting the elongation of messenger RNA (Palomino and Martin 2014). The mechanism of RIF resistance in MTB is associated with mutation of the rpoB gene (Isakova et al. 2018). Some $96 \%$ of the mutation codons of RIF resistant MTB isolates mostly occur in 81 bp spanning codons (507-533), called the rifampicin resistance determining region (RRDR). Among these codons, rров 516, 526 and 531 provided the highest level of resistance with percentage 70-95\% (Palomino and Martin 2014)(Tajbakhsh et al. 2018). Another powerful drug for MTB is isoniazid and mutations in several genes such as $k a t G$, inhA, oxyR, $k a s A, a h p C$ and $n d h$ are responsible for INH drug resistance. Most INH resistance is caused by the katG gene that codes for the catalase-peroxidase enzyme, a key factor in mycolic acid biosynthesis. The most common mutation in INH-resistant strains is katG315 (50-95\%) (Gupta et al. 2013) (Pandey et al. 2017) (Ravibalan et al. 2015).

Here, we examined the mutations of drug-resistant MTB strains emphasizing on the $r p o B$ and $k a t G$ genes in Northeastern Thailand populations using PCR and DNA sequencing methods. 


\section{Materials and Methods}

Sample sources and processing: A total of 357 MTB isolates were randomly selected from the TB laboratory at the Office of Disease Prevention and Control Center (DPC) $7^{\text {th }}, 8^{\text {th }}, 9^{\text {th }}$ and $10^{\text {th }}$ (Khon Kaen Province, Udon Thani Province, Nakhon Ratchasima Province and Ubon Ratchathani Province, respectively) between 2013 and 2016 in Northeastern Thailand. Among these samples, 92 isolates were found with drug resistance (rifampicin and isoniazid) by testing with the standard proportion method in all DPC centers (Rueangsak et al. 2020). In this study, 65 drug-resistant MTB isolates were used for detection of mutation patterns in Northeastern Thailand. All isolates were confirmed as MTB by observing culture positive on Lowenstein-Jensen medium and using immunochromatographic assay (ICA) kit (SD Bioline TB Ag MPT64 rapid test) to detect and amplify real-time PCR.

DNA extraction: Genomic DNA of the 65 drug-resistant isolates of Mycobacterium tuberculosis (26 resistant to both RIF and INH, 33 mono-resistant to isoniazid and 6 mono- resistant to rifampin) were extracted using the CTAB (cetyl trimethylammonium bromide) method (Van Embden et al. 1993). In two microcentrifuge tubes, each $400 \mu \mathrm{L}$ of bacterial cell suspension was transferred. After that, both tubes were put on heat block with the temperature at $80^{\circ} \mathrm{C}$ for $20 \mathrm{mins}$. After adding all chemical reagents, the DNA pellets were re-dissolved in $50 \mu \mathrm{L}$ of TE buffer and stored at $-20{ }^{\circ} \mathrm{C}$ and $-70{ }^{\circ} \mathrm{C}$ until required for further use. The estimation of DNA concentration was done by using a spectrophotometer (NanoDrop 2000c, USA) with the absorbance at a wavelength of $260 \mathrm{~nm}$.

PCR amplification: Conventional polymerase chain reaction was used to determine mutations in 4 regions for the $r p o B$ gene codons 516, 526, 531 and 533 and 1 region for the $k a t G$ gene codon 315 using specific primers (Table 1) (Nurpermatasari et al. 2018) (Ahmed et al. 2013). For each condition, the preparation of master mix concentration and cycling temperature were modified from the methods of (Allegui et al. 2012) (Tajbakhsh et al. 2018) (Farnia et al. 2010).

Amplification reactions for the rpoB516 and katG315 were performed in a final volume of 50 $\mu \mathrm{L}$ containing $0.5 \mu \mathrm{L}$ of $2.5 \mathrm{mM}$ dNTPs, $5 \mu \mathrm{L}$ of $10 X B u f f e r, 0.25 \mu \mathrm{L}$ of $5 \mathrm{U} / \mu \mathrm{L}$ Taq polymerase, 1.66 $\mu \mathrm{L}$ of $50 \mathrm{mM} \mathrm{MgCl} 2,40.59 \mu \mathrm{L}$ sterile DI water, $0.5 \mu \mathrm{L}$ of each forward and reverse $10 \mu \mathrm{M}$ primers and $1 \mu \mathrm{L}$ of 20ng of genomic DNA. Similar concentrations of all reagents were also used for amplifying the rpoB531 and rpoB526 genes with a final volume of $25 \mu \mathrm{L}$ composed of $0.25 \mu \mathrm{L}$ of dNTPs, $2.5 \mu \mathrm{L}$ of Buffer, $0.2 \mu \mathrm{L}$ of Taq polymerase, $0.5 \mu \mathrm{L}$ (for 531) and $1 \mu \mathrm{L}$ (for 526) of $\mathrm{MgCl}_{2}, 18.55 \mu \mathrm{L}$ (for 531) and $18.05 \mu \mathrm{L}$ (for 526) of sterile DI water, $1 \mu \mathrm{L}$ of each primer and $1 \mu \mathrm{L}$ of DNA. For the rpoB533 amplification, the PCR reaction was performed in a final volume of $25 \mu \mathrm{L}$ containing the same concentrations of the above reagents accompanied by dNTPs $(2 \mu \mathrm{L})$, Buffer $(2.5 \mu \mathrm{L})$, Taq $(0.25 \mu \mathrm{L})$, $\mathrm{MgCl}_{2}(2.75 \mu \mathrm{L})$, DI water $(13 \mu \mathrm{L})$, forward primer $(0.5 \mu \mathrm{L})$, reverse primer $(2 \mu \mathrm{L})$ and DNA $(2 \mu \mathrm{L})$.

The DNA amplifications were performed in a thermal cycler, FlexCycler2, (Analytik Jena AG, Germany). Cycling temperatures for the $r p o B 516$ and $k a t G 315$ genes were initial denaturing at $96{ }^{\circ} \mathrm{C}$ for $3 \mathrm{~min} ; 23$ cycles of $95{ }^{\circ} \mathrm{C}$ for $50 \mathrm{~s}, 68^{\circ} \mathrm{C}$ for $40 \mathrm{~s}$, and $72{ }^{\circ} \mathrm{C}$ for $1 \mathrm{~min}$; and final elongation at $72{ }^{\circ} \mathrm{C}$ for $7 \mathrm{~min}$. For rров 531 and 526 genes, the following temperature cycles were used: initial denaturing at $95^{\circ} \mathrm{C}$ for $5 \mathrm{~min}, 40$ cycles of $94^{\circ} \mathrm{C}$ for $1 \mathrm{~min}, 58^{\circ} \mathrm{C}$ (for 531) and $55^{\circ} \mathrm{C}$ (for 526) for $1 \mathrm{~min}, 72{ }^{\circ} \mathrm{C}$ for 1 
min, and a final extension at $72{ }^{\circ} \mathrm{C}$ for $10 \mathrm{~min}$. Furthermore, initial denaturing at $95{ }^{\circ} \mathrm{C}$ for 5 mins; 40 cycles of $95{ }^{\circ} \mathrm{C}$ for $30 \mathrm{~s}, 68{ }^{\circ} \mathrm{C}$ for $30 \mathrm{~s}$, and $72{ }^{\circ} \mathrm{C}$ for $30 \mathrm{~s}$; and final elongation at $72{ }^{\circ} \mathrm{C}$ for 7 min were used as cycling temperatures for amplifying the rpoB 533 primer. All PCR fragments were analyzed by agarose gel electrophoresis using $1.5 \%$ agarose. The gels were exposed to UV light with photos taken by a GeneFlash gel documentation system (Syngene, USA).

DNA sequencing: Two primers: $r p o B-F$ (5'-TACGGTCGGCGAGCTGATCC-3') and rpoB-R (5'TACGGCGTTTCGATGAACC-3') were used to amplify a 411-bp fragment (1119 - 1532bp) of the rроB gene, containing 81-bp (RRDR region). The region of the $435 \mathrm{bp}$ (669-1103bp) katG gene was amplified with a set of primers F-GCAGATGGGGCTGATCTACG and R-AACGGGTCCGGGATGG TG. Before sequencing, PCR amplification reactions were modified following (Farnia et al. 2010) and (Jaiswal et al. 2017). Final volumes of $50 \mu \mathrm{L}$ were used for the $r p o B$ and $k a t G$ genes. For the $r p o B$ gene, sterile DI water $32.9 \mu \mathrm{L}, 10 X$ Xuffer $5 \mu \mathrm{L}, 5 \mathrm{U} / \mu \mathrm{L}$ Taq Polymerase $0.5 \mu \mathrm{L}, 2.5 \mathrm{mM}$ dNTPs $4 \mu \mathrm{L}, 50 \mathrm{mM}$ $\mathrm{MgCl}_{2} 1 \mu \mathrm{L}, 10 \mu \mathrm{M}$ Forward and Reverse Primers $0.8 \mu \mathrm{L}$ each and $4 \mu \mathrm{L}$ of $20 \mathrm{ng}$ DNA were used, while sterile DI water $(25.75 \mu \mathrm{L}), 10 X$ Xuffer $(6.25 \mu \mathrm{L}), 5 \mathrm{U} / \mu \mathrm{L}$ Taq Polymerase $(0.5 \mu \mathrm{L}), 2.5 \mathrm{mM}$ dNTPs $(4$ $\mu \mathrm{L}), 50 \mathrm{mM} \mathrm{MgCl} 2(2 \mu \mathrm{L}), 10 \mu \mathrm{M}$ forward and reverse primers $(3.75 \mu \mathrm{L}$ for each) and $4 \mu \mathrm{L}$ of $20 \mathrm{ng}$ DNA were used to amplify the $k a t G$ gene.

PCR conditions were as follows: initial denaturation of $95^{\circ} \mathrm{C}$ for $5 \min (r p o B)$ and $95^{\circ} \mathrm{C}$ for 3 $\min (k a t G)$, followed by 40 cycles of $95{ }^{\circ} \mathrm{C}$ for $30 \mathrm{~s}$, annealing at $69{ }^{\circ} \mathrm{C}$ for $30 \mathrm{~s}$, extension of $72{ }^{\circ} \mathrm{C}$ for $30 \mathrm{~s}$ and final extension of $72{ }^{\circ} \mathrm{C}$ for $7 \mathrm{~min}$ for the $r p o B$ gene followed by 35 cycles of $95{ }^{\circ} \mathrm{C}$ for $45 \mathrm{~s}$, annealing at $64{ }^{\circ} \mathrm{C}$ for $45 \mathrm{~s}$, extension of $72{ }^{\circ} \mathrm{C}$ for $1 \mathrm{~min}$ and final extension of $72{ }^{\circ} \mathrm{C}$ for 5 min for the $k a t G$ gene. The PCR products were analyzed by electrophoresis on $2 \%$ agarose gel under ultraviolet light. After amplification, the PCR products containing specific genes and specific portions were sent to a sequencing company (Ward Medic), including the gel purification step.

Sequence Analysis: The sequencing data obtained from the company were aligned with the wild type sequences of $r p o B$ and katG genes for H37Rv (GenBank accession NC_000962.3) using the BioEdit bioinformatic tool. Then, mutation codons and types of mutation in the samples were examined. For the $r p o B$ gene, the nucleotide numbering system was based on $E$. coli.

Two isolates with novel mutation in the katG365 gene can be accessed (GenBank accession no. MZ093466, MZ093467).

\section{Results}

Out of 357 MTB isolates, 92 samples (25.8\%) were found with drug resistance, as already described by (Rueangsak et al. 2020). Of the 92 drug-resistant samples, 38 (41.3\%) were multi-drug resistant, while $46(50 \%)$ and $8(8.7 \%)$ were mono-resistant to isoniazid and mono-resistant to rifampicin, respectively. Sixty-five drug-resistant samples (26 multi-drug resistant, 33 mono-resistant to isoniazid and 6 mono-resistant to rifampicin) were used to find mutations in the hot spot regions of the rpoB and $k a t G$ genes. 


\section{PCR amplification results}

To detect mutations in the rpoB516,526,531,533 and katG315 genes, each reaction for amplifying target size was optimized using the H37RV reference strain as the DNA template (Fig. 1 Optimization results of rpoB516, 526, 531, 533 and katG315 primers by PCR shown by $1.5 \%$ agarose gel electrophoresis). Fifty-nine mono-resistant isoniazid isolates were detected by the kat $G 315$ primer to determine the mutations. Among the 56 isoniazid resistant samples, 45 (80.4\%) were identified as mutation in the katG315 gene. The remaining 3 samples were not differentiated by PCR.

Consequently, 32 mono-resistant rifampicin isolates were tested to observe mutations using all $r p o B$ primers individually. Of $32 \mathrm{R}$ to RIF samples, the rpoB516 gene mutation was found in 10 (31.2\%), rpoB526 mutation was observed in $5(15.6 \%)$ and $11(34.4 \%)$ were identified as mutation in the rpoB531 gene. There were no mutation isolates with the rpoB533 primer. Therefore, the rpoB531 gene mutation had the highest percentage followed by rроB516 and rpoB526.

Twenty-six MDR isolates were detected to observe combined mutations of both genes using rpoB516,526,531,533 and katG315 primers. A total of 13 out of 26 (50\%) MDR cases showed mutations in both genes, while 4 isolates harbored no mutation in MDR samples. Mutation in the $k a t G$ gene alone was found in 8 samples, whereas 1 sample was found to have mutation in the $r p o B$ gene alone in MDR isolates. Six samples showed no mutation in mono R to INH and 3 samples of mono R to INH were not differentiated by PCR. Three samples were found as no mutation in mono $\mathrm{R}$ to RIF samples. Hence, 15 samples for the $r p o B$ gene and 14 samples for the $k a t G$ gene were selected for DNA sequencing to detect mutation sites not detected by PCR. 


\section{DNA sequencing results}

PCR amplification for DNA sequencing of the rpoB and $k a t G$ genes was optimized using the $\mathrm{H} 37 \mathrm{Rv}$ reference strain as the DNA template (Fig. 2 Optimization results of $r p o B$ and $k a t G$ genes by PCR shown by $2 \%$ agarose gel electrophoresis). Fifteen isolates that exhibited the rpoB gene with no mutation and 14 isolates that showed no mutation at katG315 codon by PCR were sequenced. Our analysis detected 5 mutated positions distributed among 4 codons within RRDR of the rpoB gene. Of the 15 isolates, 7 had mutation at codon 531 with amino acid changes at the position of TCG-TTG (Ser-Leu), while mutation at codon 526 of CAC-CGC (His-Arg) occurred in 3 isolates and changes of CAC-TAC (His-Tyr) occurred in 2 isolates. Moreover, 1 mutation at codon 516 GAC-GTC (Asp-Val) was identified, while a mutation at codon 533 displayed CTG-CCG (Leu-Pro) amino acid change. No mutation was detected in 1 isolate.

Among the 14 isolates that showed no mutation at katG315 codon, 2 isolates had mutation at codon 365 CCG-CGG (Pro-Arg) (Fig. 3 Chromatogram of the nucleotide substitution (CCG-CGG) detected in two novel isolates at katG365 codon). These were recognized as novel mutations and no mutations were observed in 12 samples. The above 3 samples that were not differentiated by PCR revealed no mutation with the sequencing method.

\section{Distribution of mutation profiles based on PCR and DNA sequencing methods}

The $k a t G$ gene mutations occurred in 47 (79.7\%) of the $59 \mathrm{R}$ to INH samples. For the rpoB gene, 31 (96.9\%) were observed as mutations in $32 \mathrm{R}$ to RIF isolates. Of the $47 \mathrm{~kat} G$ mutation samples, 45 (95.7\%) had mutations in katG315 codon and 2 (4.3\%) showed mutations in katG365 codon (Fig. 4 (a) Mutation frequency percentage in the $k a t G$ gene among $47 \mathrm{R}$ to INH isolates). Moreover, 18 (58.1\%) at rpoB531, 11 (35.5\%) mutations at rpoB516, 10 (32.3\%) mutations at rpoB526 and 1 (3.2\%) mutation at rpoB533 were found between $31 \mathrm{R}$ to RIF samples in this study (Fig. 4 (b) Mutation frequency percentage in the rpoB gene among $31 \mathrm{R}$ to RIF isolates). Out of $26 \mathrm{MDR}$ isolates, combined mutations of the rpoB and $k a t G$ genes were found in $22(84.6 \%)$ samples, while no mutation was observed in 1 (3.8\%) and only rров mutation occurred in 3 (11.5\%) samples (Fig. 4 (c) Mutation genes frequency percentage in $26 \mathrm{MDR}$ isolates). Finally, geographical distribution of the $r p o B$ and $k a t G$ gene mutation samples found in each province of Northeastern Thailand were shown. (Fig. 5 Geographical distribution of the rрoB and $k a t G$ genes mutation samples found in each province of Northeastern Thailand region).

\section{Discussion}

This is the first study determining the distribution of Mycobacterium tuberculosis mutation genes in Northeastern Thailand. We found $41.3 \%$ as MDR, $50 \%$ as R to INH and $8.7 \%$ as R to RIF among 92 drug-resistant isolates collected from 4 DPC centers (17 provinces) in Northeastern Thailand that has 20 provinces. Among the 92 isolates, 65 drug-resistant samples (26 MDR, $33 \mathrm{R}$ to INH and $6 \mathrm{R}$ to RIF) were used to detect the mutation genes of $r p o B$ and $k a t G$ using PCR and DNA sequencing methods. RIF resistance is caused by mutation in the $r p o B$ gene, encoding the $\beta$-subunit of the DNAdependent RNA polymerase (Jureen et al. 2006) (Chaves et al. 2000). More than 95\% of rpoB mutations 
in RIF-resistant clinical isolates have been found within the rifampicin resistant determining region (RRDR) (González et al. 1999). Our findings revealed that $96.9 \%$ of $r p o B$ gene mutations were observed within the RRDR region. Our result was similar to a report in Bangladesh that also showed 96.43\% of $r p o B$ gene point mutation in the RRDR (Mistri et al. 2016). Other studies have documented the presence of common and novel rpoB mutations outside the RRDR (Mani et al. 2001) (Aparna Lingala et al. 2010). According to our size of product, we only determined the most prevalent mutation codons between the positions 454-591 including the RRDR region. Inside the 81-bp RRDR, mutations within codons 516, 526 and 531 are responsible for up to $90 \%$ of RIF-resistant strains and recognized as the most frequent codons (Pang et al. 2013) (Williams et al. 1994). Out of the rpoB gene mutation isolates in our study, $58.1 \%$ were detected at rpoB531,35.5\% at rpoB516 and 32.3\% at rpoB526. Therefore, the most prevalent mutation codon was rpoB531, consistent with other findings in the Kyrgyz Republic (64.8\%) (Isakova et al. 2018), Shanghai (53.8\%) (Fan et al. 2003) and North India (66.7\%) (Makadia et al. 2012). Most studies in China (Yue et al. 2003), Vietnam (Caws et al. 2006) and Singapore (Lee et al. 2005) exhibited the rpoB526 codon as the second highest mutation frequency, different from our results. Moreover, only $1(3.2 \%)$ sample was found to have mutation in rpoB533 (Leu-Pro). This codon 533 was also detected in a study in Ratchaburi Province, Thailand as a novel mutation; however, different amino acids indicated rpoB533 (Leu-Arg) (Jintaridh et al. 2014). In accordance with our study, reports from Thailand by (Prammananan et al. 2008) and Taiwan by (Qian et al. 2002) displayed rpoB533 (Leu-Pro) with percentages of 2.1 and 3, respectively. Furthermore, double point mutation was determined in 7 samples and triple point mutation was identified in 1 sample in our study. In our research, rpoB531 codon that expressed highest mutation percentages, could be applied as an indicator to investigate rifampicin resistant Mycobacterium tuberculosis isolates in this area.

Nearly all rifampicin-resistant strains are further resistant to other drugs, especially to isoniazid. Thus, rifampicin resistance is recognized as a surrogate marker for MDR-TB (Traore et al. 2000). Detection of resistance for another drug in this study was isoniazid that inhibits the synthesis of mycolic acids and acts as a prodrug that is activated by the catalase-peroxidase enzyme, katG (Jena et al. 2014) (Timmins and Deretic 2006). Our report showed that katG gene mutation was found at the rate of 79.7\%, in which $95.7 \%$ had mutations in katG315 codon and $4.3 \%$ harbored mutation in katG365 codon. The percentage of $79.7 \%$ for the $k a t G$ gene mutation was consistent with earlier studies in Thailand (Boonaiam et al. 2010) (Suthum et al. 2020) and other Southeast Asian Countries (Ismail et al. 2016) (Caws et al. 2006) (Valvatne et al. 2009) (Liu et al. 2018) (Cheng et al. 2021). The prevalence of katG315 mutation varied according to the geographical region: Southeast Asia (78.4\%) (Seifert et al. 2015), Vietnam (85.3\%) (Hang et al. 2019), China (59.4\%) (Wu et al. 2006), the Netherlands (53\%) (Van Soolingen et al. 2000), Japan (22\%) (Ando et al. 2010) and Singapore (26\%) (Lee et al. 1999). Furthermore, our results revealed higher percentage of katG315 mutation in R to INH isolates than in MDR strains (53.3\% and 46.7\%, respectively). Two isolates of novel mutation at katG365 (GenBank accession no. MZ093466, MZ093467) with the amino acid substitution of CCG-CGG (Pro-Arg) were exhibited in our report. As previously mentioned, the katG315 gene mutation provided higher percentages, and this mutation codon could be utilized as an indicator for the detection of isoniazid resistance to Mycobacterium tuberculosis isolates in this region. 
After PCR amplification, 15 samples of R to RIF that did not show any mutation with primers of the PCR method were selected for $r p o B$ gene sequencing to discover more mutation codons. These 15 isolates showed single point mutation within RRDR of the rpoB gene in 14 and no mutation in 1 sample. In 15 isolates of $\mathrm{R}$ to RIF, we found 7 samples at rpoB531 mutation with the amino acid substitution of TCG-TTG (Ser-Leu). Moreover, mutation at codon 526 of CAC-CGC (His-Arg) occurred in 3 isolates and changes of CAC-TAC (His-Tyr) occurred in 2 isolates only, while the amino acid change pattern of mutation at codon 516 was GAC-GTC (Asp-Val). Furthermore, mutation at codon 533 displayed CTGCCG (Leu-Pro) amino acid change. katG sequencing was performed in the 14 isolates that showed the $k a t G$ gene, with no mutation in 5 MDR samples, $6 \mathrm{R}$ to INH samples and 3 samples not detected by PCR. Among the 14 isolates, 12 exhibited no mutation and 2 displayed mutation in 365 codons (Pro-Arg). The 3 samples that were not detected by PCR revealed no mutation with the sequencing method. Mutation patterns performed by DNA sequencing in this study showed missense mutation in all isolates.

According to Fig. 5, mutations of the $r p o B$ and $k a t G$ genes in each province were widely distributed. The katG315 gene mutation samples were fully distributed throughout Northeastern Thailand and detected in every province except Bueng Kan that also showed no mutation samples. Moreover, rpoB531 gene mutation samples were also widespread and found in nearly every province except for Bueng Kan, Chaiyaphum, Nakhon Ratchasima, Yasothon and Maha Sarakham. Higher distribution of mutation codons was found in provinces located near the Laos border. In Sakon Nakhon and Amnat Charoen Provinces, 2 isolates (one in each province) showing novel mutation were detected, while 1 isolate of rpoB533 gene mutation was found in Mukdahan Province.

When comparing PCR and DNA sequencing methods, discordant results were found for detection of the $r p o B$ gene but not for the $k a t G$ gene. PCR did not identify 7 isolates of rpoB531 mutation, 5 samples of rpoB526 mutation, 1 sample of rpoB516 mutation and 1 sample of rpoB533 mutation, possibly because the isolates contained heterogeneous populations of bacteria with mutated and wild type $r р о B$ alleles, leading to amplification of the wild type PCR product (Ullah et al. 2019). No mutations were detected in 1 isolate of R to RIF and 12 isolates of R to INH by both PCR and DNA sequencing. Mutations outside the rроB and katG genes were not considered in this study. The DNA sequencing method showed greater sensitivity and specificity than PCR but the latter is more appropriate for use as a screening method to obtain faster results in low resource countries. Our results showed similar percentages of mutation codons reported in Thailand and Southeast Asian Countries except for katG315 percentage and having novel mutation of katG365 codon.

Study limitations were as follows. Gene mutation of $k a t G, \operatorname{ahpC}, \operatorname{inh} A$ and $k a s A$ can cause isoniazid resistance (Zhang et al. 1992); however, we only detected katG gene mutation that provided high-level resistance. Even though we identified the $k a t G$ gene mutation, the amino acid change pattern of this gene mutation could not be performed by sequencing, especially in katG315. Furthermore, a larger sample size would further validate our findings. We were unable to identify the entire genes of $r p o B$ and $k a t G$ because we focused on the most prevalent mutation sites for sequencing. Therefore, further studies should sequence the entire $r p o B$ and $k a t G$ genes to obtain more accurate results. The mutations reported here should be considered in the development of new molecular diagnostic methods for implementation in Northeastern Thailand. 


\section{Conclusions}

Even though DNA sequencing has great accuracy, conventional PCR methods can be applied as an initial marker for the screening of rifampicin and isoniazid in Northeastern Thailand. Our results showed that rpoB531 codon and katG315 codon expressed highest mutation percentages and could be utilized as indicators to investigate rifampicin and isoniazid resistant Mycobacterium tuberculosis isolates in this area. Two isolates with novel mutation at katG365, with amino acid substitution CCGCGG (Pro-Arg) were exhibited in our report. The mutations reported here should be considered in the development of new molecular diagnostic methods for implementation in Northeastern Thailand. These novel techniques could reduce mortality and morbidity and provide effective treatment to ameliorate the formation of further resistant strains and spread of disease in Northeastern Thailand.

\section{Acknowledgements}

This research project was supported by Khon Kaen University Research Grant (project number 590038 and 6100033) and Centre for Research and Development of Medical Diagnostic Laboratories, Khon Kaen University. We would like to thank the KKU Scholarship for ASEAN and GMS Countries' Personnel of Academic Year 2019, Khon Kaen University for providing a scholarship for Ei Phoo Thwe. Special thanks also go to Miss Kulrattana Rueangsak for her technical assistance.

\section{Declarations}

Funding: The present study was supported by Centre for Research and Development in Medical Diagnostic Laboratory, Faculty of Associated Medical Sciences, Khon Kaen University and the Graduate School, Khon Kaen University, Thailand.

Conflict of interest: The author declares that they have no conflict of interest.

Availability of data and material: Not applicable

Code availability: Not applicable

Authors' contributions: Not applicable

Ethical Approval: This study was approved by Khon Kaen University Ethics Committee for Human Research (HE631314).

Consent to participate: Not applicable

Consent for publication: Not applicable 


\section{References}

Ahmed M, Ahmed AR, Mohammed S (2013) First experience with using simple polymerase chain reactionbased methods as an alternative to phenotypic drug susceptibility testing for Myobacterium tuberculosis in Iraq. Int J Appl Basic Med Res 3:98 - 105. https://doi.org/10.4103/2229-516x.117069

Allegui Z, Ghariani A, Draoui H, et al (2012) Detection of isoniazid and rifampin resistance of Mycobacterium tuberculosis by a multiplex allele-specific polymerase chain reaction (PCR) assay. Int J Mycobacteriology 1:34-39. https://doi.org/10.1016/j.ijmyco.2012.01.006

Ando H, Kondo Y, Suetake T, et al (2010) Identification of katG mutations associated with high-level isoniazid resistance in Mycobacterium tuberculosis. Antimicrob Agents Chemother 54:1793-1799. https://doi.org/10.1128/AAC.01691-09

Anukool U, Phunpae P, Tharinjaroen CS, et al (2020) Genotypic distribution and a potential diagnostic assay of multidrug-resistant tuberculosis in northern thailand. Infect Drug Resist 13:3375-3382. https://doi.org/10.2147/IDR.S263082

Aparna Lingala ML, Srikantam A, Jain S, et al (2010) Clinical and geographical profiles of $r p o B$ gene mutations in Mycobacterium tuberculosis isolates from Hyderabad and Koraput in India. J. Microbiol. Antimicrob 2:13-18.

Boonaiam S, Chaiprasert A, Prammananan T, Leechawengwongs M (2010) Genotypic analysis of genes associated with isoniazid and ethionamide resistance in MDR-TB isolates from Thailand. Clin Microbiol Infect 16:396-399. https://doi.org/10.1111/j.1469-0691.2009.02838

Caws M, Minh Duy P, Quang Tho D, et al (2006) Mutations Prevalent among Rifampin- and IsoniazidResistant Mycobacterium tuberculosis Isolates from a Hospital in Vietnam. J Clin Microbiol 44:23332337. https://doi.org/10.1128/JCM.00330-06

Chaves F, Alonso-Sanz M, Rebollo MJ, et al (2000) rpoB mutations as an epidemiologic marker in rifampinresistant Mycobacterium tuberculosis. Int J Tuberc Lung Dis 4(8):765-770.

Cheng S, Hide M, Pheng SH, et al (2021) Resistance to Second-Line Anti-TB Drugs in Cambodia: A Phenotypic and Genetic Study. Infect Drug Resist Volume 14:1089-1104. https://doi.org/10.2147/idr.s289907

Fan XY, Hu ZY, Xu FH, et al (2003) Rapid detection of rpoB gene mutations in rifampin-resistant Mycobacterium tuberculosis isolates in Shanghai by using the amplification refractory mutation system. $\mathrm{J}$ Clin Microbiol 41:993-997. https://doi.org/10.1128/JCM.41.3.993-997.2003

Farnia P, Taghavi K, Sh S, et al (2010) Susceptibility Testing Multiplex - PCR, PCR SSCP and PCR ELISA Mycobacteriology Research Center (MRC), 2168099; Tehran: National Research Institute of Tuberculosis and Lung Diseases 978-600. https://doi.org/10.13140/RG.2.2.14291.07200

Genestet C, Hodille E, Berland JL, et al (2020) Whole-genome sequencing in drug susceptibility testing of Mycobacterium tuberculosis in routine practice in Lyon, France. Int J Antimicrob Agents 55:105912. 
https://doi.org/10.1016/j.ijantimicag.2020.105912

González N, Torres MJ, Aznar J, Palomares JC (1999) Molecular analysis of rifampin and isoniazid resistance of Mycobacterium tuberculosis clinical isolates in Seville, Spain. Tuber Lung Dis 79:187-190. https://doi.org/10.1054/tuld.1998.0195

Gupta A, Prakash P, Singh SK, Anupurba S (2013) Rapid Genotypic Detection of rpoB and katG Gene Mutations in Mycobacterium tuberculosis Clinical Isolates from Northern India as Determined by MASPCR. J Clin Lab Anal 27:31-37. https://doi.org/10.1002/jcla.21558

Hang NT Le, Hijikata M, Maeda S, et al (2019) Whole genome sequencing, analyses of drug resistanceconferring mutations, and correlation with transmission of Mycobacterium tuberculosis carrying katGS315T in Hanoi, Vietnam. Sci Rep 9:15354. https://doi.org/10.1038/s41598-019-51812-7

Isakova J, Sovkhozova N, Vinnikov D, et al (2018) Mutations of $r p o B, k a t G$, inhA and ahp genes in rifampicin and isoniazid-resistant Mycobacterium tuberculosis in Kyrgyz Republic. BMC Microbiol 18:1-8. https://doi.org/10.1186/s12866-018-1168-x

Ismail N-A, Fazli Ismail M, Suraiya S, et al (2016) Genotypic Detection of rpoB and katG Gene Mutations Associated with Rifampicin and Isoniazid Resistance in Mycobacterium tuberculosis Isolates: A Local Scenario (Kelantan). Malays J Med Sci 23(1): 22-26.

Jaiswal I, Jain A, Singh P, et al (2017) Mutations in $k a t G$ and $i n h A$ genes of isoniazid-resistant and -sensitive clinical isolates of Mycobacterium tuberculosis from cases of pulmonary tuberculosis and their association with minimum inhibitory concentration of isoniazid. Clin Epidemiol Glob Heal 5:143-147. https://doi.org/10.1016/j.cegh.2016.08.008

Jaksuwan R, Tharavichikul P, Patumanond J, et al (2017) Genotypic distribution of multidrug-resistant and extensively drug-resistant tuberculosis in northern Thailand. Infect Drug Resist 10:167-174. https://doi.org/10.2147/IDR.S130203

Jang JG, Chung JH (2020) Diagnosis and treatment of multidrug-resistant tuberculosis. Yeungnam Univ J Med 37:277-285. https://doi.org/10.12701/yujm.2020.00626

Jena L, Waghmare P, Kashikar S, et al (2014) Computational approach to understanding the mechanism of action of isoniazid, an anti-TB drug. Int J Mycobacteriology 3:276-282. https://doi.org/10.1016/j.ijmyco.2014.08.003

Jintaridh P, Ramasoota P, Pyar K, et al (2014) Novel Mutation Detection in rpoB of Rifampicin-resistant Mycobacterium tuberculosis using pyrosequencing. Southeast Asian J Trop Med public health 45:843852.

Jureen P, Engstrand L, Eriksson S, et al (2006) Rapid detection of rifampin resistance in Mycobacterium tuberculosis by pyrosequencing technology. J Clin Microbiol 44:1925-1929. https://doi.org/10.1128/JCM.02210-05

Lange C, Aarnoutse RE, Alffenaar JWC, et al (2019) Management of patients with multidrug-resistant 
tuberculosis. Int J Tuberc Lung Dis 23:645-662. https://doi.org/10.5588/ijtld.18.0622

Lee ASG, Lim IHK, Tang LLH, et al (1999) Contribution of kasA analysis to detection of isoniazid-resistant Mycobacterium tuberculosis in Singapore. Antimicrob Agents Chemother 43:2087-2089. https://doi.org/10.1128/aac.43.8.2087

Lee ASG, Lim IHK, Tang LLH, Sin YW (2005) High frequency of mutations in the rpoB gene in rifampinresistant clinical isolates of Mycobacterium tuberculosis from Singapore. J. Clin. Microbiol. 43:20262027

Li MC, Chen R, Lin SQ, et al (2020) Detecting Ethambutol Resistance in Mycobacterium tuberculosis Isolates in China: A Comparison Between Phenotypic Drug Susceptibility Testing Methods and DNA Sequencing of embAB. Front Microbiol 11:1-7. https://doi.org/10.3389/fmicb.2020.00781

Liu L, Jiang F, Chen L, et al (2018) The impact of combined gene mutations in inhA and $\operatorname{ahpC}$ genes on high levels of isoniazid resistance amongst $k a t G$ non-315 in multidrug-resistant tuberculosis isolates from China. Emerg Microbes Infect 7:183. https://doi.org/10.1038/s41426-018-0184-0

Makadia JS, Jain A, Patra SK, et al (2012) Emerging trend of mutation profile of $r p o B$ gene in MDR tuberculosis, North India. Indian J Clin Biochem 27:370-374. https://doi.org/10.1007/s12291-012-0228-5

Mani C, Selvakumar N, Narayanan S, Narayanan PR (2001) Mutations in the rpoB gene of multidrug-resistant Mycobacterium tuberculosis clinical isolates from India. J Clin Microbiol 39:2987-2990. https://doi.org/10.1128/JCM.39.8.2987-2990.2001

Mistri SK, Sultana M, Kamal SMM, et al (2016) Evaluation of efficiency of nested multiplex allele-specific PCR assay for detection of multidrug resistant tuberculosis directly from sputum samples. Lett Appl Microbiol 62:411-418. https://doi.org/10.1111/lam.12564

Nimri L, Samara H, Batchoun R (2011) Detection of mutations associated with multidrug-resistant Mycobacterium tuberculosis clinical isolates. FEMS Immunol Med Microbiol 62:321-327. https://doi.org/10.1111/j.1574-695X.2011.00814.x

Nurpermatasari A, Harahap U, Siagian P (2018) Identification gene mutations rpoB cause of multidrug resistance tuberculosis in Haji Adam Malik hospital. Asian J Pharm Clin Res 11:155-158. https://doi.org/10.22159/ajpcr.2018.v11s1.26595

Palomino JC, Martin A (2014) Drug resistance mechanisms in Mycobacterium tuberculosis. Antibiotics 3:317340 .

Pandey S, Lamichhane A, Byanjankar A, et al (2017) Direct detection of $r p o B$ and kat $G$ gene mutations of Mycobacterium tuberculosis in clinical samples. Asian Pac J Trop Biomed 7:698-701. https://doi.org/10.1016/j.apjtb.2017.07.018

Pang Y, Lu J, Wang Y, et al (2013) Study of the rifampin monoresistance mechanism in Mycobacterium tuberculosis. Antimicrob Agents Chemother 57:893-900. https://doi.org/10.1128/AAC.01024-12 
Prammananan T, Cheunoy W, Taechamahapun D, et al (2008) Distribution of $r p o B$ mutations among multidrugresistant Mycobacterium tuberculosis (MDRTB) strains from Thailand and development of a rapid method for mutation detection. Clin Microbiol Infect 14:446-453. https://doi.org/10.1111/j.14690691.2008.01951

Qian L, Abe C, Lin TP, et al (2002) rpoB genotypes of Mycobacterium tuberculosis Beijing family isolates from East Asian countries. J Clin Microbiol 40:1091-1094. https://doi.org/10.1128/JCM.40.3.1091-1094.2002

Ravibalan T, Samrot A V, Maruthai K, et al (2015) Evaluation of Multiplex Polymerase Chain Reaction Assay for the Detection of katG (S315T) gene Mutation in Mycobacterium tuberculosis Isolates from Puducherry, South India. J Pure Appl Microbiol 9:2339-2345.

Rueangsak K, Tanuchit S, Chumpol J, et al (2020) 24-locus MIRU-VNTR and Spoligotyping analysis of drugresistant Mycobacterium tuberculosis strains isolated from Northeastern Thailand. Infect Genet Evol 85:104449. https://doi.org/10.1016/j.meegid.2020.104449

Seifert M, Catanzaro D, Catanzaro A, Rodwell TC (2015) Genetic mutations associated with isoniazid resistance in Mycobacterium tuberculosis: A systematic review. PLoS One 10:1-13. https://doi.org/10.1371/journal.pone.0119628

Suthum K, Samosornsuk W, Samosornsuk S (2020) Characterization of katG, inhA, rpoB and pncA in Mycobacterium tuberculosis isolates from MDR-TB risk patients in Thailand. J Infect Dev Ctries 14:268276. https://doi.org/10.3855/jidc. 11974

Tajbakhsh A, Ghasemi F, Mirbagheri SZ, et al (2018) Investigation of the rpoB Mutations Causing Rifampin Resistance by Rapid Screening in Mycobacterium tuberculosis in North-East of Iran. Iran J Pathol. 13(4):429-437.

Timmins GS, Deretic V (2006) Mechanisms of action of isoniazid. Mol. Microbiol. 62:1220-1227.

Traore H, Fissette K, Bastian I, et al (2000) Detection of rifampicin resistance in Mycobacterium tuberculosis isolates from diverse countries by a commercial line probe assay as an initial indicator of multidrug resistance. Int J Tuberc Lung Dis 4(5):481-484.

Ullah I, Ahmad W, Shah AA, et al (2019) Detection of rifampicin resistance of Mycobacterium tuberculosis using multiplex allele specific polymerase chain reaction (MAS-PCR) in Pakistan. Infect Genet Evol 71:42-46. https://doi.org/10.1016/j.meegid.2019.03.007

Valvatne H, Syre H, Kross M, et al (2009) Isoniazid and rifampicin resistance-associated mutations in Mycobacterium tuberculosis isolates from Yangon, Myanmar: Implications for rapid molecular testing. J Antimicrob Chemother 64:694-701. https://doi.org/10.1093/jac/dkp292

Van Embden JDA, Cave MD, Crawford JT, et al (1993) Strain Identification of Mycobacterium tuberculosis by DNA Fingerprinting: Recommendations for a Standardized Methodology. J. Clin. Microbiol 31:406-409.

Van Soolingen D, De Haas PEW, Rogier Van Doorn H, et al (2000) Mutations at Amino Acid Position 315 of the katG Gene Are Associated with High-Level Resistance to Isoniazid, Other Drug Resistance, and 
Successful Transmission of Mycobacterium tuberculosis in The Netherlands. J. Infect. Dis. 182:1788-90.

Williams DL, Waguespack C, Eisenach K, et al (1994) Characterization of Rifampin Resistance in Pathogenic Mycobacteria. Antimicrob. Agents Chemother 38:2380-2386.

World Health Organizatin (2020) . Global Tuberculosis Report 2020. Available at: http://apps.who.int/bookorders, Accessed date: 11 March 2021.

Wu XQ, Lu Y, Zhang JX, et al (2006) Detection of the mutations in katG315 and inhA-15 of Mycobacterium tuberculosis strains isolated from Chinese patients. Chin Med J (Engl) 119:230-233. https://doi.org/10.1097/00029330-200602010-00011

Yue J, Shi W, Xie J, et al (2003) Mutations in the rpoB gene of multidrug-resistant Mycobacterium tuberculosis isolates from China. J Clin Microbiol 41:2209-2212. https://doi.org/10.1128/JCM.41.5.2209-2212.2003

Zhang Y, Heym B, Allen B, et al (1992) The catalase - Peroxidase gene and isoniazid resistance of Mycobacterium tuberculosis. Nature 358:591-593. https://doi.org/10.1038/358591a0 
Figures

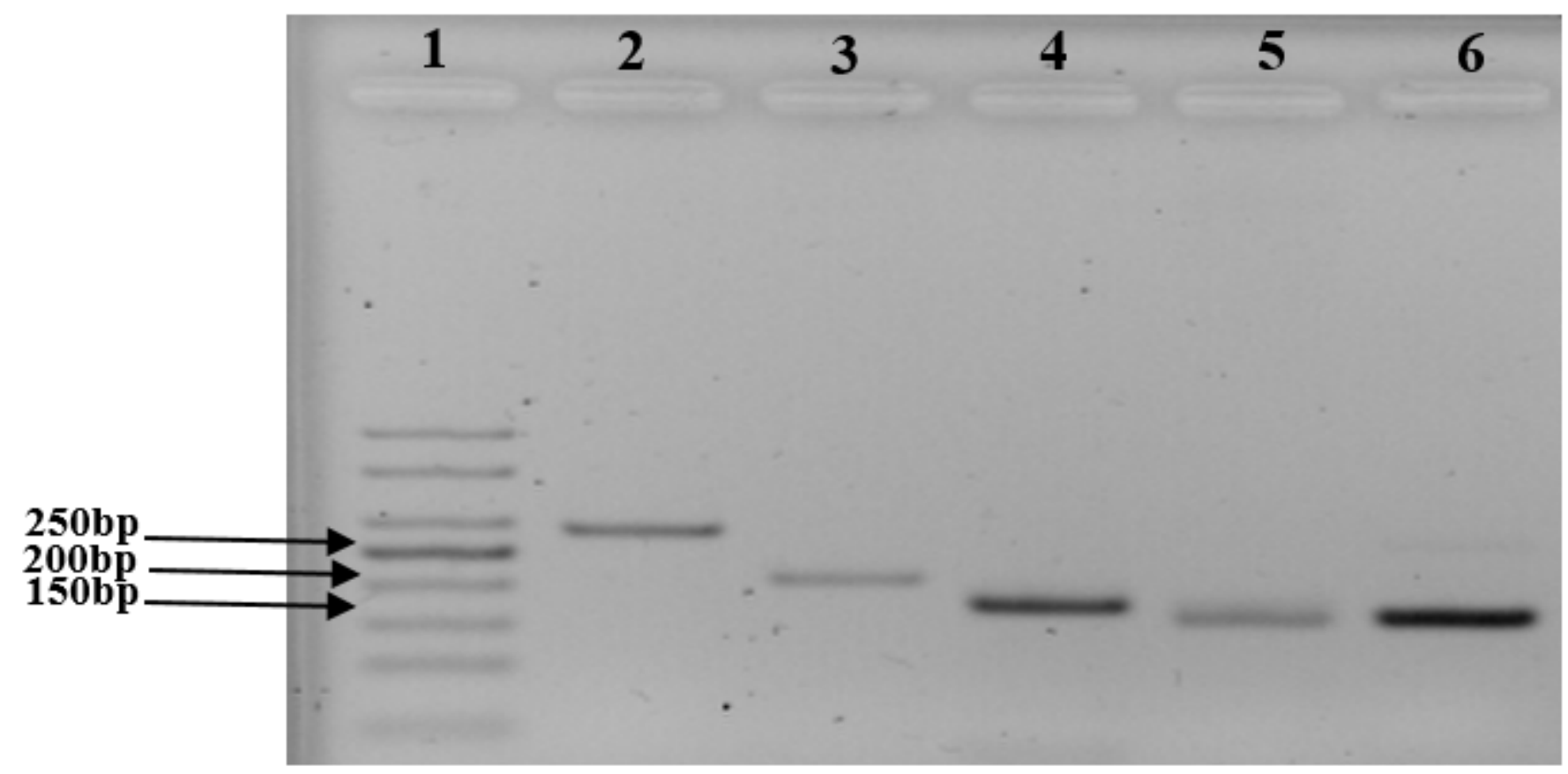

Fig. 1

Figure 1

Optimization results of rpoB516, 526, 531, 533 and katG315 primers by PCR shown by $1.5 \%$ agarose gel electrophoresis 


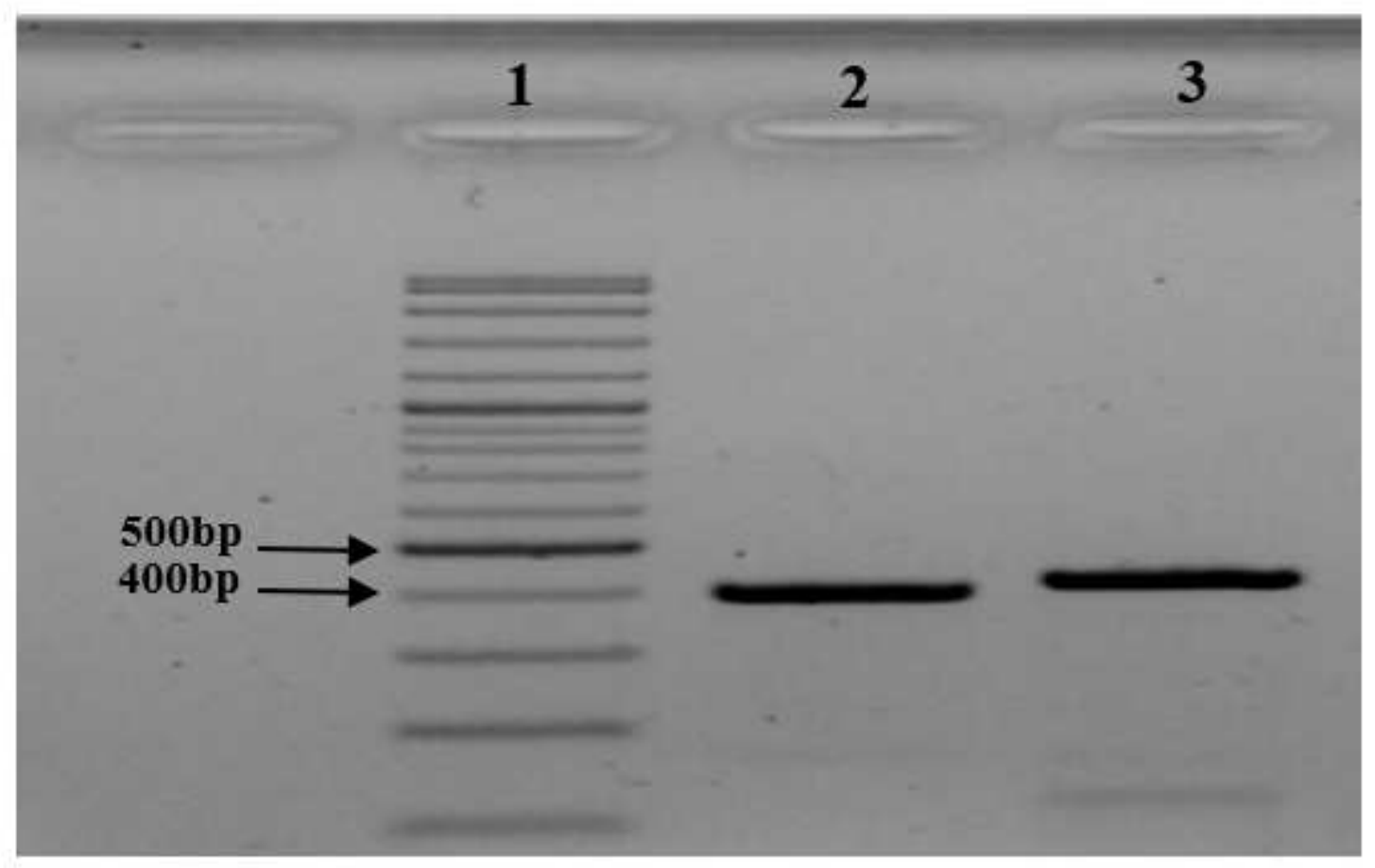

Fig. 2

Figure 2

Optimization results of rpoB and katG genes by PCR shown by $2 \%$ agarose gel electrophoresis 


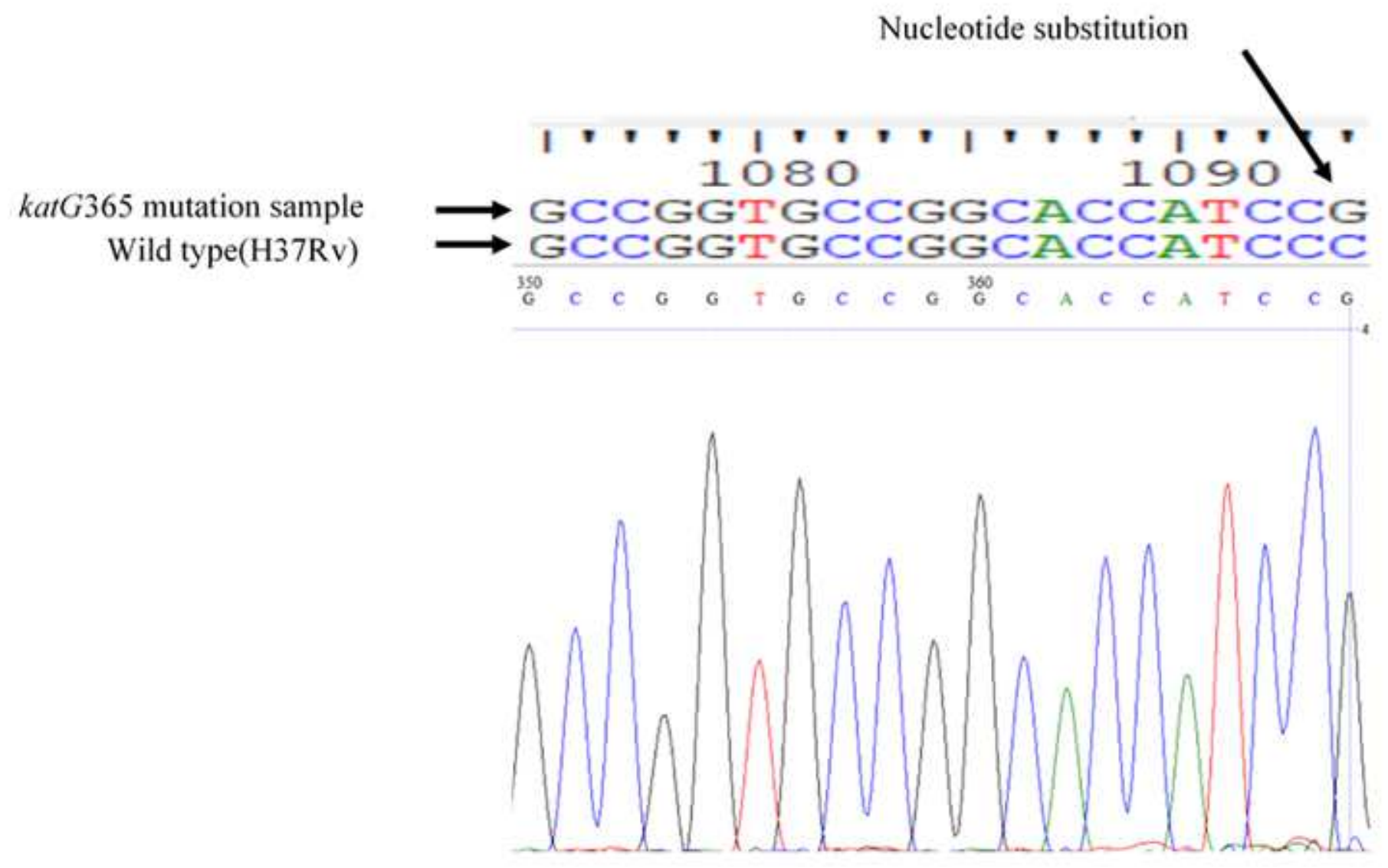

Fig. 3

\section{Figure 3}

Chromatogram of the nucleotide substitution (CCG-CGG) detected in two novel isolates at katG365 codon

(a)

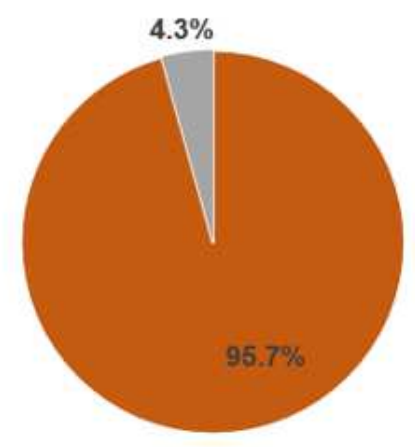

- katG315 = katG365 (b)

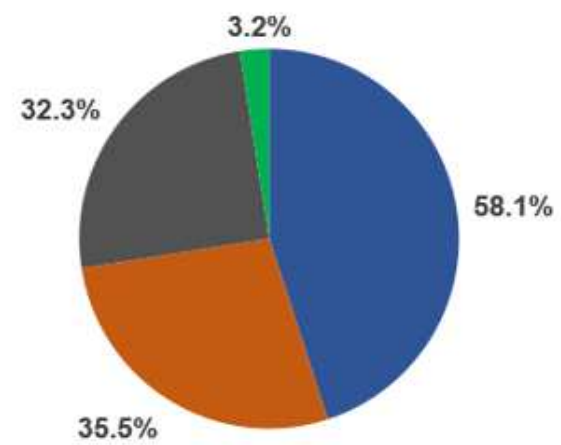

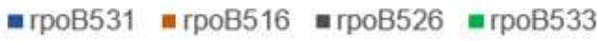

(c)

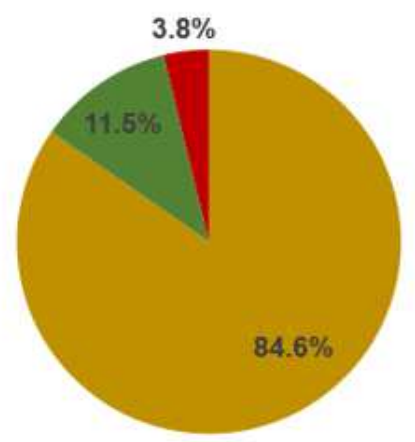

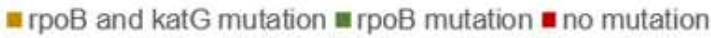

Figure 4 
(a) Mutation frequency percentage in the katG gene among $47 \mathrm{R}$ to INH isolates). Moreover, $18(58.1 \%)$ at rpoB531, 11 (35.5\%) mutations at rpoB516, 10 (32.3\%) mutations at rpoB526 and 1 (3.2\%) mutation at rpoB533 were found between 31 R to RIF samples in this study (Fig. 4 (b) Mutation frequency percentage in the rpoB gene among $31 \mathrm{R}$ to RIF isolates). Out of $26 \mathrm{MDR}$ isolates, combined mutations of the rpoB and katG genes were found in $22(84.6 \%)$ samples, while no mutation was observed in $1(3.8 \%)$ and only rpoB mutation occurred in 3 (11.5\%) samples (Fig. 4 (c) Mutation genes frequency percentage in 26 MDR isolates

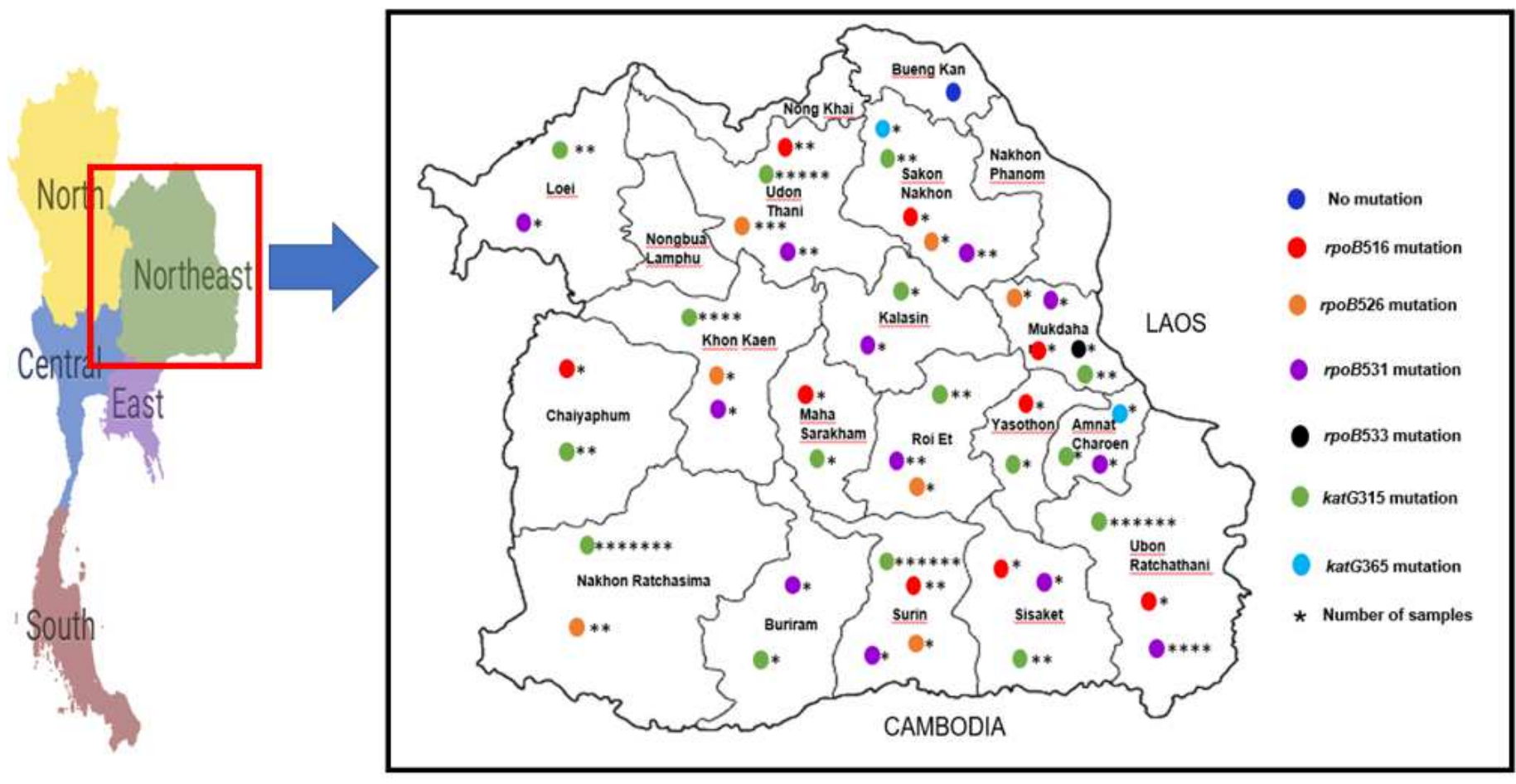

Fig. 5

\section{Figure 5}

Geographical distribution of the rpoB and katG genes mutation samples found in each province of Northeastern Thailand region 